\title{
PROFIL KUALITATIF KOMPONEN EKSTRAK KUNYIT PUTIH (Curcuma zedoaria) DAN PENGARUHNYA TERHADAP PROFIL HEMATOLOGI MENCIT YANG DIINFEKSI Salmonella typhimurium
}

\author{
Sri Novita Primawati ${ }^{1)}$, Dwi Soelistya D.J ${ }^{2)}$, Lalu Zulkifli ${ }^{2)}$ \\ (1) PS Pendidikan Biologi FPMIPA IKIP Mataram, (2) Magister Pendidikan IPA, \\ Universitas Mataram
}

\begin{abstract}
ABSTRAK
Curcuma zedoaria merupakan tanaman herbal yang telah banyak digunakan sebagai sebagai antikanker, analgesik, antiinflamasi, dan antioksidan. Namun, uji klinis yang memanfaatkan C. zedoaria untuk mencegah dan mengobati penyakit-penyakit infeksi belum banyak dilakukan. Penelitian ini bertujuan untuk mengetahui profil kualitatif ekstrak kunyit putih dan pengaruhnya terhadap profil hematologi mencit Balb/c (M. musculus) yang diinfeksi $S$. typhimurium. Mencit diberikan ekstrak kunyit putih selama 7 hari, pada hari ke 7 diinfeksi $S$. typhimurium pada bagian intraperitonial. Pengamatan profil hematologi dilakukan pada hari ke 0 (sebelum pemberian perlakuan), hari ke 7, hari ke 10 dan hari ke 13. Penelitian ini dirancang dengan rancangan acak lengkap (RAL), kemudian data yang diperoleh dianalisis dengan ANOVA. Hasil penelitian menunjukkan pengaruh yang signifikan $(p<0,05)$ dari perlakuan terhadap proliferasi leukosit mencit Balb/c dengan waktu pengamatan, macam perlakuan (saline, ekstrak kunyit putih, ekstrak kunyit putih dan infeksi S. typhimurium, infeksi $S$. typhimurium saja) dan interaksinya. Tidak ditemukan pengaruh yang signifikan dari perlakuan terhadap proliferasi eritrosit $(\mathrm{p}>0,05)$ baik dari segi waktu pengamatan, jenis perlakuan maupun interaksi keduanya. KLT dilakukan untuk mengetahui profil kualitatif komponen ekstrak metanol kunyit. Diperoleh 5 noda dengan warna hijau berpendar, dengan nilai Rf 0,$224 ; 0,346 ; 0,644 ; 0,832$; dan 0,879 , secara berturut turut untuk masing faksi $\mathrm{A}, \mathrm{B}$, C, D, dan E.
\end{abstract}

Kata Kunci: Imunomodulator, Ekstrak Kunyit Putih, S. typhimurium, Hematologi,

Profil kualitatif.

\begin{abstract}
Curcuma zedoaria is an herbal plant that has been widely used as anticancer, analgesic, antiinflammatory, and antioxidants. However, clinical trials utilizing $C$. zedoaria to prevent and treat infectious diseases has not been much done. This study aims to determine the qualitative profile of white turmeric extract and its effect on hematological profile of mice Balb/c $(M$. musculus) infected with S. typhimurium. Mice were treated with a white turmeric extract for 7 days, on day 7 infected with S. typhimurium in the intraperitonial. Observation on hematology profile performed on day 0 (before administration of treatment), day 7, day 10 and day 13 . The study was designed with a completely randomized design (CRD), then the data were analyzed with ANOVA. Results of this study showed a significant ( $p<0.05$ ) effect of treatment on the leukocyte proliferation of mice Balb / c with the time of observation, range of treatment (saline, white turmeric extract, turmeric extract white and S. typhimurium infection, infection with S. typhimurium alone) and interactions. There was no signifinat effect of treatment on the proliferation of erythrocytes $(p>0.05)$ in terms of the time of observation, type of treatment and its interaction. TLC was done to determine the qualitative
\end{abstract}


profile component of the methanol extract of turmeric white. Five green fluorescent spots were observed with $\mathrm{Rf}$ values of with $\mathrm{Rf}$ values of $0.224,0.346,0.644,0.832,0.879$ for faction $\mathrm{A}, \mathrm{B}, \mathrm{C}, \mathrm{D}$ and $\mathrm{E}$, respectively.

Keywords: Immunomodulators, White turmeric extract, S. typhimurium, Hematology, qualitative profile.

\section{PENDAHULUAN}

$\mathrm{D}$ i Indonesia penyakit demam tifoid atau yang lebih dikenal dengan tifus yang merupakan penyakit endemik. Angka kejadian penyakit tifus di Indonesia rata-rata $900.000 \mathrm{kasus} / \mathrm{tahun}$ dengan angka kematian lebih dari 20.000 dan kejadian terbanyak ditemukan pada usia 3-19 tahun (Anonim, 2009). Oleh sebab itu sistem kekebalan atau imunitas sangat penting untuk melawan patogen seperti bakteri, virus, protozoa, jamur, dan lain sebagainya. Telah dilakukan berbagai upaya untuk menjaga kestabilan sistem imun, termasuk diantaranya penggunaan imunomodulator.

Kunyit putih (Curcuma zedoaria) merupakan salah satu tanaman herbal yang digunakan sebagai imunomodulator. Senyawa dalam tanaman herbal ini mampu memperbanyak jumlah limfosit, meningkatkan toksisitas sel pembunuh kanker (natural killer), sintesis antibodi spesifik dan merangsang aktivitas makrofag. Sifat-sifat tersebut akan menguatkan mekanisme pertahanan tubuh (Christine, 2007).

Beberapa penelitian laboratorium telah membuktikan khasiatnya dalam uji klinis sebagai antioksidan, antikanker dan mengatasi peradangan (anti inflamasi) (Bright, 2008). Namun, uji klinis yang memanfaatkan $C$. zedoaria untuk mencegah dan mengobati penyakit-penyakit infeksi belum banyak dilakukan. Oleh sebab itu penelitian ini dilakukan untuk mengetahui pengaruh $C$. zedoaria dalam meningkatkan respon imun seluler pada infeksi Salmonella typhimurium

\section{BAHAN DAN METODE}

Rimpang kunyit putih diiris tipis dan dikeringankan untuk memperoleh serbuk kasar yang kemudian akan dimaserasi dengan metanol (1:4) selama 72 jam. Lalu disaring dengan kertas Whatman. Cairan yang didapat kemudian dievaporasi dengan Rotary Vacum Evaporator dengan suhu $40^{\circ} \mathrm{C}$. Ekstrak metanol kunyit putih yang diperoleh disimpan selama 1 hari untuk menguapkan metanol jika masih ada yang tertinggal. Kemudian dilarutkan dengan 100 1 aquades sebelum diberikan pada hewan uji. Metode Saraswati dan Sutiningsih yang dimodifikasi (2005).

\section{Perhitungan Proliferasi Leukosit}

Pengamatan total sel leukosit menggunakan larutan turk, kemudian dihitung menggunakan kamar hitung hemositometer. Setelah diperoleh jumlah total sel pada ke empat pojok dari kamar hitung, jumlah sel tersebut kemudian dibagi empat. Hasil yang diperoleh menunjukkan jumlah leukosit dalam $0,1 \mathrm{~mm}^{3}$. Untuk mengetahui jumlah leukosit per L darah, dengan mengkalikan jumlah leukosit dalam $0,1 \mathrm{~mm}^{3}$ dengan faktor 50 (Hansen, 2009).

\section{Perhitungan Proliferasi Eritrosit}

Pengamatan ini menggunakan larutan Hayem untuk pengecetan eritrosit. Penghitungannya menggunakan metode 
yang hampir sama, namun daerah yang dibaca adalah kotak besar dibagian tengah dari kamar hitung. Penghitungan dimulai dari sudut kiri atas, terus ke kanan kemudian turun ke bawah dan dari kanan ke kiri. Lalu turun lagi ke bawah dan dimulai lagi dari kiri ke kanan (Hansen, 2009).

Setelah diperoleh jumlah total sel pada ke lima bidang besar, jumlah sel yang dihitung dibagi dengan volume bilik hitung kemudian dikalikan pengenceran. Untuk mempermudah penghitungan dapat langsung menggunakan rumus jumlah sel yang dihitung dikalikan 10.000 .

\section{Pengamatan Profil Kualitatif Komponen}

Untuk mengetahui profil kualitatif komponen dalam ekstraksi C. zedoaria menggunakan kromatografi lapis tipis (KLT). Plat silika dimasukkan ke dalam bejana KLT yang sudah jenuh dengan eluen dan dibiarkan sampai eluen merambat naik hingga garis akhir. Selanjutnya, diangkat dan dibiarkan mengering. Setelah itu dianalisis dengan menggunakan sinar UV pada panjang gelombang $254 \mathrm{~nm}$ dan $366 \mathrm{~nm}$. Setiap bercak yang terdeteksi dilingkari dan diamati warna yang ditimbulkan. Harga Rf-nya ditentukan dengan rumus (Sudarma, 2009) :
Jarak zat (spot) yang bergerak ke atas

$\mathrm{Rf}=$

Jarak permukaan eluen

\section{HASIL DAN PEMBAHASAN}

\section{Proliferasi Leukosit}

Pemberian perlakuan berupa infeksi S. typhimurium pada penelitian ini bertujuan untuk melihat respon imun mencit ketika terinfeksi. Proliferasi leukosit yang diamati selama penelitian dapat dilihat pada gambar 1 yang menunjukkan total leukosit antar perlakuan dan kontrol dengan waktu pemanenan darah.

Jika dilihat dari grafik diatas, tampak adanya peningkatan proliferasi leukosit mencit yang diberikan perlakuan (B2, B3 dan B4) dibandingkan dengan mencit kontrol (B1). Hal ini sejalan dengan fakta bahwa ketika benda asing (ekstrak metanol kunyit putih dan infeksi Salmonella) masuk ke dalam tubuh, maka tubuh akan memberikan respon pertahanan tubuh (imunitas). Tubuh akan merespon dengan peningkatan proliferasi leukosit berupa aktifasi neutrofil, makrofag, monosit, limfosit, eusinofil dan basofil (Janeway et al., 2005). Respon inilah yang menyebabkan terjadinya perbedaan proliferasi leukosit dibandingkan kontrol. 


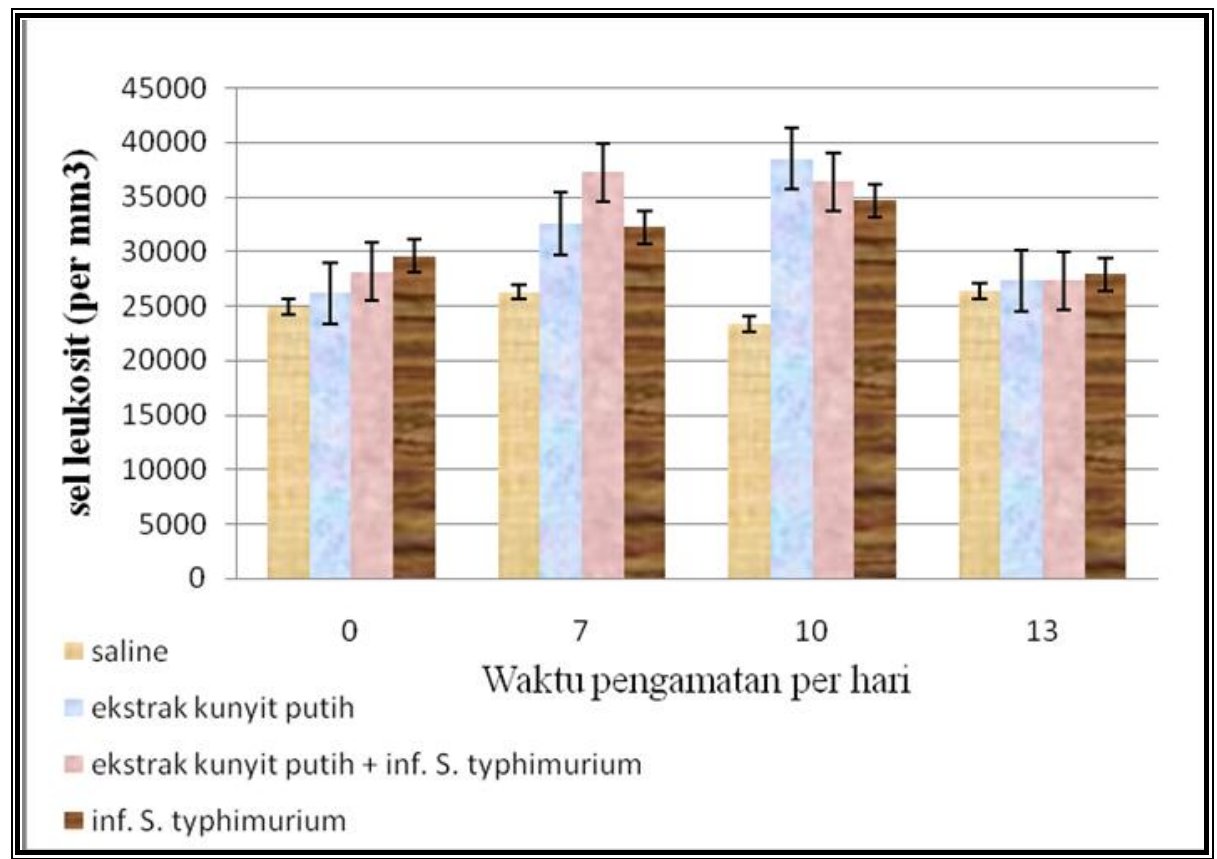

Gambar 1. Pengaruh ekstrak metanol kunyit putih (C. zedoaria) dan S. typhimurium terhadap proliferasi leukosit pada 4 waktu pengamatan $(0,7,10$ dan 13 hari).

Ditemukan juga perbedaan yang bermakna $\left\{\mathrm{F}\right.$ hitung $(7,40)>\mathrm{F}$ tabel $_{0,05}$ $(3,96)\}$ antara mencit yang diberikan ekstrak metanol kunyit putih (B2) dengan mencit yang diberikan ekstrak metanol kunyit putih dan diinfeksi S. typhimurium (B3). Pemberian ekstrak metanol kunyit putih secara oral (in vivo) seperti yang telah dilakukan oleh Varalakshmi et al., (2008) dapat meningkatkan mitogen yang berpotensi merangsang proliferasi sel $\mathrm{T}$, sel $\mathrm{B}$, makrofag dan neutrofil serta meningkatkan kerja fagositosis secara fagosit.

Selain itu kurkumin juga mengatur sitokin inflamasi seperti IL-1 $\beta$, IL-2, IL-6, IL-12, TNF $\alpha$ dan IFN $\gamma$ (Bright, 2007). Sitokin diproduksi dan disekresi oleh sel $\mathrm{T}$ untuk menginduksi proliferasi sel dan mendukung pertumbuhan jangka panjang sel T (Soeroso, 2007). Pelepasan IL-2 dari sel T mengakibatkan aktivasi sel $\mathrm{T}$ lainnya yang memiliki reseptor IL-2. IL-2 mampu merangsang sel-sel $\mathrm{T}$ yang ada di sekitarnya untuk berproliferasi (Kresno, 2000). Hal ini menyebabkan proliferasi leukosit meningkat ketika diberikan ekstrak metanol kunyit putih.

Ketika respon imun mencit terpapar $S$. typhimurium, maka tubuh akan mengaktifkan makrofag, kemudian makrofag akan mensekresi Interleukin-1 (IL-1), IL-6, IL-8, IL-12, IL-15, IL-18 dan TNF $\alpha$. IL-1, IL-6, dan TNF $\alpha$ bekerja sinergis untuk meningkatkan aktivasi sel $\mathrm{T}$ dan respon radang akut. IL-8 membantu menarik neutrofil ke tempat infeksi, hal ini menyebabkan proliferasi leukosit mencit meningkat ketika terinfeksi (Santos et al., 2002). Dengan pemberian ekstrak metanol kunyit putih sebagai imunomodulator dapat menjaga kestabilan sistem imunitas tubuh mencit meskipun diberikan infeksi.

Jika tubuh mencit terinfeksi, maka sistem imunitas yang telah dikuatkan dengan pemberian ekstrak kunyit putih akan membunuh bakteri tersebut dalam waktu cepat dan efektif. Terlihat dari grafik untuk B3, maksimal ploriferasi adalah pada hari ke7 yaitu 2 jam setelah diinfeksi. Diduga ketika pengamatan 2 jam setelah infeksi pada mencit, respon imun seluler yang paling aktif 
berperan membunuh bakteri S. typhimurium dengan mekanisme fagositosis.

Pada hari ke 7 diambil darah untuk pengamatan proliferasi leukosit, diperoleh peningkatan proliferasi leukosit dibandingkan 0 hari. Ini menunjukkan bahwa kurkumin yang terdapat dalam ekstrak metanol kunyit putih dapat meningkatkan proliferasi leukosit. Hasil penelitian ini sejalan dengan penelitian yang dilakukan oleh Carvalho et al., (2010) yang menyatakan bahwa pemberian ekstrak $C$. zedoaria secara oral dapat meningkatkan jumlah total leukosit yang berarti sehingga dapat menghambat pertumbuhan sel tumor.

Untuk pengamatan pada hari ke- 0 dan ke-7 (A1A2) menunjukkan perbedaan yang bermakna $\left\{\mathrm{F}\right.$ hitung $(4,29)>\mathrm{F}$ tabel $_{0,05}$ $(3,96)\}$ terhadap waktu pengamatan 10 hari (A3). Pada hari ke 0 belum diinfeksikan sedangkan pada hari ke 7 pengamatan dilakukan 2 jam pasca penyuntikan sehingga respon yang terbaca masih berupa respon imun dini yang teraktivasi sekitar 0-4 jam sejak pemaparan benda asing. Berbeda dengan waktu pengamatan pada hari ke-10, yang berarti hari ke 3 pasca infeksi. Pada hari ke-10 terlihat jelas bahwa mencit telah terinfeksi, bulu pada bagian punggung dan kepala yang menggumpal karena keringat yang dikeluarkan lebih banyak, aktifitas mencit diam dan menunjukkan respon seperti demam pada manusia serta nafsu makan dan minum yang sangat berkurang.

Pada sistem imun adaptif sel limfosit merupakan sel yang paling berpengaruh melawan antigen dari luar. Sel limfosit terutama sel limfosit $\mathrm{T}$ yang teraktivasi oleh keberadaan antigen seperti $S$. typhimurium akan menghasilkan senyawa interleukin seperti interleukin 2 (IL-2). IL-2 mampu menstimulasi sel $\mathrm{T}$ yang memproduksinya dan sel $\mathrm{T}$ yang ada di sekitarnya untuk terus berproliferasi, demikian seterusnya, sehingga jumlah total leukosit dari mencit akan meningkat.

Pada pengamatan 0 hari, 7 hari dan 10 hari (A1A2A3) menunjukkan perbedaan yang bermakna $\left\{\mathrm{F}\right.$ hitung $(5,16)>\mathrm{F}$ tabel $\mathrm{l}_{0,05}$ $(3,96)\}$ terhadap waktu pengamatan 13 hari (A4). Hal ini menunjukkan bahwa pada hari ke 13 respon imun mencit cenderung mendekati kontrol yang hanya diberikan aquades. Hal ini dapat dijelaskan berdasarkan patogenis pada hari ke-13 bakteri $S$. typhimurium sudah termasuk dalam fase pembersihan yang melibatkan sistem imun spesifik khususnya sel $\mathrm{T}$ (Ugrinovic et al., dalam Lestarini, 2008).

\section{Proliferasi Eritrosit}

Pengamatan profil hematologi meliputi pengamatan proliferasi leukosit dan eritrosit. Berdasarkan penelitian yang dilakukan oleh Carvalho et al., (2010) yang menyatakan pemberian ekstrak $C$. zedoaria secara intraperitonial pada mencit dapat meningkatan jumlah total leukosit dan eritrosit secara signifikan. Hasil yang diperoleh menunjukkan hal yang berbeda, setelah dilakukan analisis secara statistik tidak terdapat perbedaan yang bermakna $\{\mathrm{F}$ hitung $(0,15)<\mathrm{F}$ tabel $\left._{0,05}(1,99)\right\}$ pada setiap perlakuan. Baik antara waktu pemaparan (perlakuan A) dengan $\mathrm{F}$ hitung $(2,54)<\mathrm{F}$ tabel $_{0,05}(2,72)$ maupun antar perlakuan (perlakuan B) dengan $\mathrm{F}$ hitung $(2,22)<\mathrm{F}$ tabel $_{0,05}(2,72)$. 
Tabel 1. Tabulasi data proliferasi leukosit

\begin{tabular}{|c|l|c|}
\hline $\begin{array}{c}\text { Waktu } \\
\text { pengamatan } \\
\text { (hari) }\end{array}$ & \multicolumn{1}{|c|}{ Perlakuan } & $\begin{array}{c}\text { Proliferasi Eritrosit } \\
\left(10^{5} / \mathrm{mm}^{3}\right)\end{array}$ \\
\hline \multirow{4}{*}{0} & Saline & $8,16 \pm 0,56$ \\
\cline { 2 - 3 } & Eks. Kunyit putih & $8,76 \pm 0,11$ \\
\cline { 2 - 3 } & Eks. Kunyit putih + Infeksi S. typhimurium & $7,84 \pm 8,51$ \\
\cline { 2 - 3 } & Infeksi S. Typhimurium & $8,02 \pm 1,06$ \\
\hline \multirow{4}{*}{7} & Saline & $8,02 \pm 0,30$ \\
\cline { 2 - 3 } & Eks. Kunyit putih & $6,78 \pm 3,56$ \\
\cline { 2 - 3 } & Eks. Kunyit putih + Infeksi S. typhimurium & $5,15 \pm 3,76$ \\
\cline { 2 - 3 } & Infeksi S. Typhimurium & $8,15 \pm 1,32$ \\
\hline \multirow{4}{*}{10} & Saline & $8,01 \pm 2,3$ \\
\cline { 2 - 3 } & Eks. Kunyit putih & $8,87 \pm 2,16$ \\
\cline { 2 - 3 } & Eks. Kunyit putih + Infeksi S. typhimurium & $8,10 \pm 8,84$ \\
\cline { 2 - 3 } & Infeksi S. Typhimurium & $8,38 \pm 8,38$ \\
\hline \multirow{3}{*}{13} & Saline & $8,89 \pm 0,22$ \\
\cline { 2 - 3 } & Eks. Kunyit putih & $7,84 \pm 0,23$ \\
\cline { 2 - 3 } & Eks. Kunyit putih + Infeksi S. typhimurium & $8,23 \pm 0,43$ \\
\cline { 2 - 3 } & Infeksi S. Typhimurium & $8,23 \pm 0,44$ \\
\hline & & \\
\hline
\end{tabular}

Hal ini diduga karena pemberian ekstrak metanol kunyit putih melalui oral dengan sonde. Pemberian secara oral harus melalui saluran pencernaan terlebih dahulu, sehingga memungkinkan ekstrak kunyit putih tersebut rusak oleh enzim pencernaan. Selain itu infeksi $S$. typhimurium yang menyerupai demam tipus pada manusia, tidak memberikan dampak berkurangnya eritrosit didalam tubuh mencit.

\section{Kandungan Komponen Kimia Dalam Ekstrak Metanol C. zedoaria.}

Kromatografi Lapis Tipis merupakan metode pemisahan suatu senyawa berdasarkan perbedaan distribusi dua fasa yaitu fasa diam dan fasa gerak. KLT analitik ini digunakan untuk mencari eluen terbaik dari beberapa eluen yang baik dalam pemisahan senyawa kurkumin. Eluen yang baik adalah eluen yang bisa memisahkan senyawa dalam jumlah yang banyak ditandai dengan munculnya noda yang berwarna hijau berpendar. Noda yang dihasilkan selanjutnya diamati di bawah sinar lampu UV pada panjang gelombang $254 \mathrm{~nm}$.

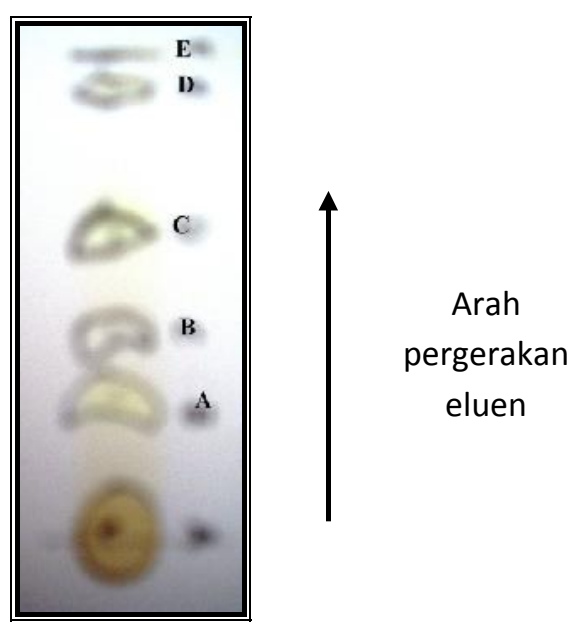

Gambar 1.Titik noda yang diperoleh dari perbandingan eluen diklorometana dan metanol (10:0)

Perbandingan eluen diklorometana : metanol (10:0) mampu memberikan pemisahan terbaik, hal ini dapat dilihat dengan adanya noda yang terpisah dengan baik dan jumlah noda paling banyak yaitu 5 noda dengan nilai Rf 0,224 (Fraksi A), 0,346 (Fraksi B), 0,644 (Fraksi C), 0,832 (Fraksi D), 0,879 (Fraksi E). Hal ini dilihat dari komposisi eluen tersebut yang bersifat non 
polar sehingga bisa memisahkan senyawa kurkumin yang juga bersifat non polar (Gambar 2).

Kurkumin merupakan senyawa non polar yang sulit larut dalam air, sehingga untuk memisahkannya dengan komponen biokimia lainnya yang terdapat di dalam esktrak metanol $C$. Zedoaria digunakan diklorometana (fase gerak) sebagai eluen yang sama-sama bersifat non polar dan dengan fase diam yang bersifat polar (silika gel Gf $254 \mathrm{~nm}$ ). Maka senyawa tersebut akan cenderung terikat dengan fase diamnya dan kurang tereluasi sehingga bercaknya berada di bawah dari senyawa yang lebih non polar (kurkumin).

\section{KESIMPULAN}

Dari hasil penelitian dan pembahasan dapat diambil kesimpulan sebagai berikut pemberian ekstrak kunyit putih berpengaruh signifikan terhadap proliferasi leukosit. Namun tidak berpengaruh terhadap proliferasi eritrosit. Metode KLT menggunakan konsentrasi eluen diklorometana didapatkan 5 noda dengan warna hijau berpendar.

\section{DAFTAR PUSTAKA}

Anonim. 2009. Demam tifoid. http://medicine.uii.ac.id/index.php/Ar tikel/Demam-Tifoid.html. Diakses pada 13 September 2012

Bright. J.J. 2007. Curcumin and Autoimmune Disease. http://www.ncbi.nlm.nih.gov/pubmed /17569223, PubMed. 595:425-51 Diakses pada 20 Mei 2011.

Christine. 2007. Thesis: Clonal propagation of C. zedoaria rosc and Zingiber zerumbet smith (zingiberaceae). Universiti Sains Malaysia, Malaysia.

Carvalho, F.R., Vassão, R.C., Nicoletti, M.A., Maria, D.A. 2010. Effect of C. zedoaria crude extract against tumor progression and immunomodulation. $J$ Venom Anim Toxins incl Trop Dis.16. 2.

Hansen, P.J. 2009. Use of a Hemacytometer. http://www.animal.UFI.

Edu/hansen/protocols/hemacytometer .htm. Diakses pada tanggal 10 Oktober 2012.

Janeway, Ch. A., Travers, P., Walport, M., and Shlomchik, M.J. 2005. Immunobiology: The Immune System In Health and Disease. Garland Science, New York.

Kresno, S.B. 2000. Imunologi: Diagnosis dan Prosedur Laboraturium. Jakarta: FKUI.

Lestarini, I.A. 2008. Pengaruh Pemberian Phyllanthus niruri L Terhadap Respon Imunitas Seluler Mencit Balb/c Yang Diinfeksi Dengan Salmonella typhimurium. Fakultas Kedokteran, Universitas Diponerogo, Semarang.

Santos, R.L., Zhang, S., Tsolis, R.M., Bäumler, A.J and Adams, L.G. 2002. Morphologic and Molecular Characterization Of S. typhimurium Infection In Neonatal Calves. Vet Pathol. 39.2:200-15

Saraswati, L.D., Sutiningsih, D. 2005. Uji Aktivitas Aprodisiaka dan Isolasi Fraksi Aktif Rimpang Temu Putih (C. zedoaria rosc) Terhadap Tikus Putih (Rattus novergicus). Fakultas Kesehatan Masyarakat, Universitas Dipenorogo. Semarang.

Soeroso, A., 2007. Sitokin. Jurnal Oftalmogi Indonesia.5. 3.

Sudarma. 2009. Kimia Bahan Alam. Fakultas MIPA Universitas Mataram, Mataram. 